DOI 10.37882/2500-3682.2020.07.18

\title{
ИЗУЧЕНИЕ ПРИЧИН, ПРЕПЯТСТВУЮЩИХ УСПЕШНОЙ РЕСОЦИАЛИЗАЦИИ ЛИЦ, ОСВОБОДИВШИХСЯ ИЗ МЕСТ ЛИШЕНИЯ СВОБОДЫ
}

\section{A STUDY OF THE CAUSES THAT HINDER SUCCESSFUL RESOCIALIZATION OF PERSONS RELEASED FROM PRISON \\ E. Raspopin}

Summary: The purpose of this work is to study the reasons that prevent successful resocialization of persons released from prison. The work was based on the study of reports of convicts, as well as their relatives and friends. According to the results of the study, three main groups of causes were identified. The first group - negative features of behavior of the former convict (laziness, idleness, bad habits, irresponsible behavior, etc.). The second group consists of negative behaviors of people around them that the former convict contacts (incorrect social circle, old connections and acquaintances, lack of support, etc.). The third group - unfavorable socio-economic conditions (difficulties in employment, difficult financial situation, etc.). The identified reasons can be considered as "targets" for organizing psych corrective work aimed at helping convicts to successfully re-socialize after their release from prison.

Keywords: resocialization, convicted, criminal behavior, repeat criminality, the psychology of prisoners.

\section{Введение}

$\mathrm{O}$ дной из основных проблем пенитенциарной системы в частности и общества в целом является повторная и рецидивная преступность. Так, за последние пять лет наблюдается сокращение общего числа зарегистрированных преступлений и числа выявленных лиц, совершивших преступления, но удельный вес повторных преступлений неуклонно растет [4]. Люди, отбывшие наказание в исправительных учреждениях, по выходу из мест лишения свободы в силу разных причин вновь совершают преступления и получают новый «срок». Эта проблема требует углубленного изучения психологии осужденных, причин их криминального поведения, а также тех личностных и социально-психологических предпосылок, которые затрудняют процесс ресоциализации бывших осужденных к жизни в законопослушном обществе.

В связи с этим целью работы выступило изучение причин, которые препятствуют успешной ресоциализации лиц, освободившихся из мест лишения свободы.
Распопин Евгений Владимирович

К.nсх.н., дочент, Уральский юридический институт МВД России (Екатеринбург)

ev73@mail.ru

Аннотация: Целью работы выступило изучение причин, препятствующих успешной ресоциализации лиц, освободившихся из мест лишения свободы. Работа строилась на основе изучения отчетов осужденных, а также их родных и близких. По результатам исследования были выделены три основные группы причин. Первая группа - негативные особенности поведения самого бывшего осужденного (лень, праздность, вредные привычки, безответственное поведение и т. п.). Вторая группа -негативные особенности поведения окружающих людей, с которыми контактирует бывший осужденный (неправильный круг общения, старые связи и знакомые, отсутствие поддержки и т. п.). Третья группа - неблагоприятные социально-экономические условия (трудности трудоустройства, тяжелое материальное положение и т. п.). Выявленные причины могут рассматриваться как «мишени» для организации психокоррекционной работы, направленной на помощь осужденным в ресоциализации после освобождения из мест лишения свободы.

Ключевые слова: ресоциализация, осужденные, криминальное поведение, повторная преступность, психология осужденных.

\section{Прочедура и методы проведения исследования}

В исследовании приняли участие следующие группы испытуемых:

1. осужденные, повторно отбывающие наказание в виде лишения свободы в исправительных учреждениях ФСИН России в количестве 135 человек;

2. близкие и родственники осужденных - участники специализированных Интернет-форумов, посвященных проблеме ресоциализации осужденных, в количестве 200 человек.

Таким образом, общий объем выборки исследования составил 335 испытуемых.

Для изучения причин и факторов, препятствующих успешной ресоциализации осужденных, были использованы следующие методы.

Методы сбора данных:

а) анализ продуктов деятельности (архивный метод) [2]. С помощью этого метода изучались причины, которые препятствуют успешной ресоциализации осужден- 
ных, по мнению их родных и близких. Для этого анализировалась переписка родных и близких осужденных, опубликованная в открытых Интернет-источниках, на специализированных форумах, где они делились своим опытом, наблюдениями, мыслями и переживаниями о проблеме;

б) интервью [5]. Этот метод применялся для опроса повторно осужденных, чья ресоциализация после предыдущих пребываний в местах лишения свободы была неуспешной. В интервью выяснялось, какие конкретные причины помешали им адаптироваться к жизни на свободе после того, как они отбыли свой предыдущий срок.

Методы обработки данных:

а) для обработки письменных сообщений родственников и опроса осужденных применялся метод контентанализа [1];

б) для математической обработки результатов исследования применялся частотный и сравнительный анализ. Сравнительный анализ проводился с помощью $\varphi^{*}$ критерия Фишера [3].

Исследование включало в себя следующие этапы:

1. на первом этапе проводился сбор данных: собирались результаты интервьюирования осужденных и переписки их близких;

2. на втором этапе при помощи контент-анализа устанавливались основные причины, препятствующий успешной ресоциализации осужденных, как по мнению самих осужденных, так и их близких;

3. на третьем этапе проводился сравнительный анализ частот упоминания причин, препятствующих успешной ресоциализации, в отчетах родственников и осужденных.

\section{Результаты исследования}

Итак, после сбора все полученные эмпирические данные (текстовые сообщения родных и близких и результаты опроса осужденных) были подвергнуты процедуре контент-анализа. Качественные единицы (категории) контент-анализа определялись по результатам прочтения отчетов испытуемых, путем установления основных тем, к которым испытуемые регулярно обращались в своих отчетах. Количественными единицами контент-анализа выступали отдельные высказывания, законченные суждения. Количественная оценка результатов контент-анализа сводилась к подсчету частоты упоминания категорий в отчетах испытуемых.

Было установлено, что в отчетах регулярно поднимаются следующие темы.

1. Сам человек: в рамках этой темы причины и факторы, затрудняющие процесс ресоциализации, рассматриваются как зависящие от самого осуж- денного. Эта категория встречалась в отчетах осужденных в 41,1 \% случаев, в отчетах родных и близких - в 49,5 \%. В свою очередь, внутри этой категории были выделены более частные и конкретные подкатегории.

В отчетах осужденных упоминались следующие подкатегории:

1) вредные привычки: алкоголь и наркотики (эта подкатегория упоминалась в отчетах осужденных в 47,8\% случаев);

2) безответственность, внешний локус контроля (17,4\%);

3) лень, праздность, разгульная жизнь, нежелание работать, а желание жить на всем готовом, рентная ориентация (15,2\%);

4) проблемы саморегуляции, эмоциональная неустойчивость, агрессивность, вспыльчивость и конфликтность (9,8\%);

5) отсутствие страха перед наказанием, чувство безнаказанности (3,3\%);

6) психологическая травма, последствия пережитого стресса после отбывания наказания в местах лишения свободы (3,3\%);

7) сохранение тюремных привычек, уголовный сценарий жизни (совершение незначительных правонарушений, тяга к «приключениям», уголовный сленг, жаргон и т.п.) (2,2\%);

8) снижение самооценки, чувство несостоятельности, никчемности, отсутствие веры в себя (1,1\%).

В отчетах родных и близких были выявлены следующие подкатегории:

1) лень, праздность, нежелание работать (эта подкатегория встречалась в отчетах родных и близких в $26 \%$ случаев);

2) манипулирование окружающими (давление на жалость или на страх, показное самобичевание, перекладывание чувства вины и ответственности на своих близких), лживость, изворотливость, болтология, пустые обещания (14\%);

3) сохранение тюремных привычек, уголовный сценарий жизни (12,7\%);

4) проблемы саморегуляции, агрессивность, вспыльчивость и конфликтность (12,7\%);

5) неадекватно завышенная самооценка, завышенные притязания, самомнение (10,7 \%);

6) вредные привычки: алкоголь и наркотики (10\%);

7) безответственность, внешний локус контроля (9,3\%);

8) снижение самооценки, чувство несостоятельности, никчемности, отсутствие веры в себя (2 \%);

9) проблемы самоорганизации, неумение планировать свою жизнь и свое будущее (1,3%);

10) отсутствие страха перед наказанием, безнаказанность (1,3\%). 
2. Другие люди: эта тема касается поведения окружающих людей, которые оказывают негативное влияние на процесс ресоциализации. Эта категория встречалась в отчетах осужденных в 21,4\% случаев, в отчетах родных и близких - в 29,7 \%. Внутри этой категории также были выделены отдельные подкатегории.

В отчетах осужденных упоминались следующие подкатегории:

1) несправедливое, предвзятое отношение со стороны окружающих, обман, провоцирование с их стороны (эта подкатегория упоминалась в отчетах осужденных в 47,9 \% случаев);

2) неправильный круг общения, старые связи и знакомые $(27,1 \%)$;

3) отсутствие поддержки, ненужность, отсутствие семьи (22,9\%);

4) сомнения и страхи у близких, отсутствие доверия к бывшему осужденному (2,1\%).

В отчетах родных и близких были выявлены следующие подкатегории:

1) неопределенность, сомнения, чувство страха, отсутствие доверия к бывшему осужденному, чувство бессилия и выгорания («опустились руки») (эта подкатегория была отмечена в отчетах родных и близких в 45,6 \% случаев);

2) чувство жалости к бывшему осужденному, оправдание его неправильного поведения, потакание его слабостям (28,9\%);

3) принятие на себя ответственности за бывшего осужденного, решение за него проблем, с которыми он должен учиться справляться сам (13,3\%);

4) неправильный круг общения, старые связи и знакомые $(8,9 \%)$;

5) бесконтрольность, некритичность, желание пустить все на самотек, неоправданная надежда, что осужденный исправится сам по себе (2,2 \%);

6) отсутствие поддержки, ненужность, отсутствие семьи $(1,1 \%)$.

3. Внешние, социально-экономические условия: эта тема касается препятствий на пути успешной ресоциализации, которые носят «обезличенный» характер, т.е. зависят не от конкретных людей, а обусловлены неблагоприятными социальными и экономическими факторами. Эта категория встречалась в отчетах осужденных в 37,5 \% случаев, в отчетах родных и близких - в 20,8 \%. Здесь также были установлены отдельные подкатегории.

В отчетах осужденных упоминались следующие подкатегории:

1) проблемы с трудоустройством, нет работы или не принимают (эта подкатегория была отмечена в от- четах осужденных в 42,9 \% случаев);

2) трудное материальное и социально-экономическое положение, проблемы с жильем и деньгами $(23,8 \%)$;

3) стигматизация, попадание под стереотип бывшего осужденного (17,9\%);

4) власть, закон, общество, государство (обезличенные) $(9,5 \%)$;

5) изменение окружающего мира, «выпадение» из жизни, непонимание уклада жизни за пределами мест лишения свободы (3,6 \%);

6) проблемы с оформлением документов (2,4 \%).

В отчетах родных и близких были выявлены следующие подкатегории:

1) изменение окружающего мира, непонимание уклада жизни за пределами мест лишения свободы (эта подкатегория была отмечена в отчетах родных и близких в 61,9 \% случаев);

2) стигматизация (17,5\%);

3) проблемы с трудоустройством (9,5 \%);

4) проблемы с оформлением документов (7,9\%);

5) проблемы с жильем и деньгами (3,2 \%).

Как видно из полученных результатов, осужденные, за редким исключением, в своих отчетах обращаются к тем же темам, что и их близкие. Различия между ними носят, главным образом, количественный характер. Это обусловило возможность проведения сравнительного анализа результатов между этими группами. Сравнительный анализ проводился с помощью $\varphi^{*}$ критерия Фишера. В итоге были получены следующие результаты.

\section{1. Различия по категории «Сам человек».}

Осужденные отмечают, что им в большей степени затрудняют процесс ресоциализации такие особенности собственного поведения, как вредные привычки ( $p \leq 0,01)$, а также безответственность и внешний локус контроля ( $p \leq 0,05)$.

Родные и близкие в большей степени обращают внимание на такие причины, как лень и праздность $(p \leq 0,05)$, сохранение тюремных привычек и уголовный сценарий жизни ( $p \leq 0,01)$.

Наконец, в целом по категории родные и близкие чаще считают, что основная причина, по которой бывшие осужденные испытывают трудности ресоциализации, лежит в них самих, т.е. успех ресоциализации зависит, прежде всего, от самих осужденных $(p \leq 0,05)$.

По остальным подкатегориям значимых различий обнаружено не было. Но это не означает, что эти подкатегории не имеют значения; это значит, что и осужденные, их близкие дают им одинаковую оценку. Так, пред- 
ставители обеих групп оказались единодушны в своем мнении о том, что процесс ресоциализации затрудняют такие причины, как проблемы саморегуляции; снижение самооценки, отсутствие веры в себя; чувство безнаказанности и отсутствие страха перед наказанием.

\section{2. Различия по категории «Другие люди».}

Осужденные чаще указывают на следующие особенности поведения окружающих людей, которые, по их мнению, негативно влияют на процесс ресоциализации: неправильный круг общения ( $p \leq 0,01)$, отсутствие поддержки, ненужность, отсутствие семьи $(p \leq 0,01)$.

Близкие в большей степени обращают внимание на такую причину, как утрата доверия к бывшему осужденному $(\mathrm{p} \leq 0,01)$.

Также необходимо обратить особое внимание на то, что близкие упоминали ряд специфических причин, таких, как: чувство жалости к бывшему осужденному, оправдание его неправильного поведения; принятие на себя ответственности за бывшего осужденного, решение за него проблем; некритичность, неоправданная надежда, что осужденный исправится сам по себе. По сути, эти причины касаются неправильного поведения самих родных и близких, и они осознают это, что позволяет рассматривать эти факторы как «мишени» для организации психокоррекционной работы с родными и близкими осужденных.

Наконец, в целом по категории родные и близкие чаще считают, что трудности ресоциализации обусловлены негативным поведением окружающих людей, чем осужденные ( $p \leq 0,05)$.

\section{3. Различия по категории «Внешние условия».}

Осужденные отмечают, что со стороны социальноэкономических условий процессу их ресоциализации в большей степени мешают такие причины, как проблемы с трудоустройством ( $\leq \leq 0,01)$, а также трудное материальное положение, проблемы с жильем и деньгами ( $\mathrm{p} \leq$ $0,01)$.

Родные и близкие осужденных в большей степени указывают на такую причину, как изменение окружающего мира, «выпадение» бывших осужденных из обычной жизни $(p \leq 0,01)$.

Наконец, в целом по категории осужденные чаще считают, что трудности ресоциализации обусловлены негативными внешними условиями и обстоятельствами, чем их родные и близкие ( $\mathrm{p} \leq 0,01)$.

Таким образом, в целом можно отметить, что осуж- денные в своих проблемах, препятствующих успешной ресоциализации, в большей степени винят внешние условия, условия окружающего мира. Близкие в качестве основных причин трудностей ресоциализации рассматривают, прежде всего, неправильное поведение самих бывших осужденных, а также негативное влияние окружающих людей, в том числе свое собственное поведение, которое, с одной стороны, потакает слабостям и безответственности бывших осужденных, с другой стороны - отражает собственное бессилие и неверие в то, что они могут исправиться. Хотя, справедливости ради необходимо признать, что последнее обстоятельство обусловлено поведением самих бывших осужденных, которые вместо того, чтобы заслужить доверие своими поступками, ведут себя безответственно по отношению к своим близким.

\section{Выводы}

Таким образом, по результатам исследования могут быть подведены следующие итоги и сделаны выводы:

1. Причины, затрудняющие процесс ресоциализации осужденных, могут быть разделены на три основные группы:

а) сам человек: в качестве причин, затрудняющих процесс ресоциализации, выступают негативные особенности поведения самого бывшего осужденного;

б) другие люди: здесь в качестве причин, затрудняющих процесс ресоциализации, выступают негативные особенности поведения окружающих людей, с которыми контактирует бывший осужденный;

в) внешние условия: здесь в качестве причин выступают неблагоприятные социальные и экономические условия.

2. В целом, осужденные в своих проблемах, препятствующих успешной ресоциализации, в большей степени винят неблагоприятные социально-экономические условия. Близкие в качестве основных причин трудностей ресоциализации рассматривают, прежде всего, неправильное поведение самих бывших осужденных, а также негативное поведение других людей. При этом в качестве негативного поведения окружающих близкие часто рассматривают свое собственное поведение.

3. Среди конкретных причин, затрудняющих процесс ресоциализации, на первый план выступают:

1) по мнению осужденных:

а) со стороны поведения самого осужденного: вредные привычки; безответственность и внешний локус контроля; лень, праздность, нежелание работать;

б) со стороны поведения окружающих людей: несправедливое, предвзятое отношение со стороны окружающих, провоцирование с их стороны; 
неправильный круг общения, старые связи и знакомые; отсутствие поддержки, ненужность, отсутствие семьи;

в) со стороны социально-экономических условий: проблемы с трудоустройством; проблемы с жильем и деньгами; стигматизация; власть, закон, общество, государство (обезличенные);

2) по мнению родных и близких:

а) со стороны поведения самого осужденного: лень, праздность, нежелание работать; манипулирование окружающими, лживость, изворотливость, пустые обещания; сохранение тюремных привычек, уголовный сценарий жизни; проблемы саморегуляции, вспыльчивость и конфликтность; неадекватно завышенные самооценка и притязания; вредные привычки; безответственность, внешний локус контроля;

б) со стороны поведения окружающих людей: сомнения и страхи у близких, отсутствие у них доверия к бывшему осужденному; чувство жалости к бывшему осужденному, оправдание его неправильного поведения; принятие на себя ответственности за бывшего осужденного, решение за него проблем; неправильный круг общения, старые связи и знакомые;

в) со стороны внешних, социально-экономических условий: изменение окружающего мира, непонимание уклада жизни за пределами мест лишения свободы; стигматизация; проблемы с трудоустройством.

4. Выявленные в ходе исследования причины, затрудняющие процесс ресоциализации, могут рассматриваться в качестве диагностических критериев оценки потенциала ресоциализации осужденных. Кроме этого, они могут рассматриваться как «мишени» для организации психокоррекционной работы, направленной на помощь осужденным в ресоциализации после освобождения из мест лишения свободы.

\section{ЛИТЕРАТУРА}

1. Бурлачук Л.Ф., Морозов С.М. Словарь-справочник по психодиагностике. - СПб.: Питер, 2002. - 528 с.

2. Дружинин В.Н. Экспериментальная психология. - СПб.: Питер, 2000. - 320 с.

3. Сидоренко Е.В. Методы математической обработки в психологии. - СПб.: Речь, 2007. - 350 с.

4. Сырейщиков Д.В. Рецидив и повторность в преступлениях, предусмотренных главой 30 Уголовного кодекса Российской Федерации // Академическая мысль. - № 4 (9). - 2019. - С. 131-134.

5. Худяков А.И. Экспериментальная психология в схемах и комментариях. - СПб.: Питер, 2008. - 320 с. 